\title{
Yield and Quality Response of Snap Bean (Phaseolus vulgaris L.) to $P$ and $S$ Fertilizers Application under Different Irrigation Regimes in Central Rift Valley of Ethiopia
}

\author{
Melkamu Hinsermu $^{1 *} \quad$ Walelign Worku $^{2} \quad$ Edossa Etissa $^{1}$ \\ 1.Ethiopian Institute of Agricultural Research, Melkassa Agricultural Research Center \\ 2.Hawassa University, College of Agriculture, School of Plant and Horticultural Sciences
}

\begin{abstract}
Snap bean (Phaseolus vulgaris L.) is a leading exportable vegetable crop and it is a protein source for consumers in many parts of Ethiopia. However, its' current national productivity of $4.12 \mathrm{t} \mathrm{ha}^{-1}$ is lower than its' potential as a result of inadequate moisture and poor soil fertility. Therefore, the field experiment was conducted at Melkassa Agricultural Research Center during the dry season in 2017 and 2018 to evaluate the response of snap bean to phosphorus and sulfur fertilizers application under different irrigation regimes on yield and quality. The experiment was laid out in split-plot design with three replications. Four drip irrigation regimes (100, 85, 70 and $55 \%$ ETc) were assigned to main-plots. Four fertilizer types $\left(0,21 \mathrm{~kg} \mathrm{P} \mathrm{ha}^{-1}, 30 \mathrm{~kg} \mathrm{~S} \mathrm{ha}^{-1}\right.$ and $21 \mathrm{~kg} \mathrm{P} \mathrm{ha}^{-1}+30 \mathrm{~kg}^{\circ}$ $\mathrm{S} \mathrm{ha}^{-1}$ ) were allocated to sub-plots. The analysis of variance revealed that the interaction effect of irrigation regimes and fertilizers application had a significant $(\mathrm{P} \leq 0.05)$ effect on first grade and total pod yield. The main effect of various irrigation regimes had a significant $(\mathrm{P} \leq 0.05)$ effect for all yield and quality parameters except, second grade pod yield and pod diameter. On the other hand, application of different fertilizers types had nonsignificant effect in all parameters. The highest marketable yield was recorded from the interaction effect of $100 \%$ ETc with different fertilizers types' application. The partial budget analysis indicated that the best treatments were 85 and $100 \%$ ETc without fertilizers application, which gave higher net benefits of 111,879.2 and 160,242.6 ETB ha-1, respectively with an acceptable marginal rate of returns for snap bean production. Therefore, snap bean producers could consider $85 \%$ ETc without fertilizers application where scarcity of irrigation water is limiting and $100 \%$ ETc without fertilizers application where there are no water shortages, in the central rift valley of Ethiopia with similar soil properties.
\end{abstract}

Keywords: fertilizers, irrigation, plati, yield

DOI: $10.7176 / J N S R / 12-15-03$

Publication date:August $31^{\text {st }} 2021$

\section{Introduction}

Snap bean (Phaseolus vulgaris L.) comprises a group of common bean that has been selected for succulent pods with reduced fiber primarily grown for its young edible and fleshly pods (Kenneth, 2012). It is a major source of carbohydrates $(39.7 \%)$, protein $(28.9 \%)$, fibre $(22 \%)$, fat $(0.88 \%)$, calcium $(1.8 \%)$, and phosphorus $(0.13 \%)$ (Ghonimy et al., 2009). Also, the most important for export with the highest share (94\%) among all vegetables (Lemma, 2011).

Even though, snap bean is an important vegetable crop, its' productivity and quality remained low and poor in Ethiopia (Amberber, 2013). National productivity in Ethiopia was $4.12 \mathrm{t} \mathrm{ha}^{-1}$, which is low (Tesfaye, 2017) compared to the world productivity of about $14.22 \mathrm{t} \mathrm{ha}^{-1}$ (CIAT, 2006) due to lack of water and nutrient management practices and improved varieties in Ethiopia (Girma, 2009). Among these constraints, inadequate moisture and low soil fertility have been the major constraints to bean production in Ethiopia (Katungi et al., 2010).

Water stress that persists during flowering period can reduce snap bean yield by 40 to $50 \%$ due to decline in leaf water potential, stomata conductance, and photosynthetic rate (Barrios et al., 2005). Not only water stress, but also poor soil fertility is a major problem affect snap bean production in Ethiopia (Tesfaye, 2017). Among the essential nutrients; P and S are limiting nutrients (Jamal et al., 2010; Khan and Mazid, 2011). In Ethiopia, the amount of available $\mathrm{P}$ in soils is largely insufficient to meet the demand of beans (Azmera and Pellegrino, 2017). $\mathrm{P}$ deficiency can reduce snap bean yield by 60 to $75 \%$ (Snapp et al., 2002).

Sulfur is limiting nutrient nowadays due to nutrient mining under zero application of sulfur fertilizer, increases crop residue removal, and poor management practices (Alemu et al., 2016). Until recently, sulfur received a little attention due to conviction for many years, that fertilizers and atmospheric inputs supplied the soil with adequate amounts of sulfur (Jamal et al., 2010). However, nowadays arable soils in many areas are proved to be sulfur deficient (Goswam, 2014). Similarly, various soil tests from sample collected in different farm fields and regions in Ethiopia showed that lack of sulfur nutrient (ATA, 2015). Thus, this experiment was carried out with the following objectives:

$>$ To evaluate the effect of phosphorus and sulfur fertilizers application under different irrigation regimes 
on yield and quality of snap bean.

$>$ To determine economically feasible phosphorus and sulfur fertilizers application and irrigation regime for snap bean production.

\section{Materials and Methods}

\subsection{Description of the Study Area}

The experiment was conducted at MARC in 2017 and 2018 during off-season. The site is found at $117 \mathrm{~km}$ South East of Addis Ababa with geographic co-ordinate of $8^{\circ} 24^{\prime} \mathrm{N}$ latitude and $39^{\circ} 12^{\prime} \mathrm{E}$ longitude. It situated at an altitude of 1550 m.a.s.l. The area receives mean annual rainfall of $763 \mathrm{~mm}$. The mean annual maximum and minimum temperature of the site is 28.6 and $13.8^{\circ} \mathrm{C}$, respectively.

\subsection{Experimental Design and Treatments}

The experiment was laid out in split-plot design with three replications. Four drip irrigation regimes $(100,85,70$, and $55 \% \mathrm{ETc})$ were assigned to main-plots. Four fertilizer types $\left(0,21 \mathrm{~kg} \mathrm{P} \mathrm{ha}^{-1}, 30 \mathrm{~kg} \mathrm{~S} \mathrm{ha}^{-1}\right.$ and $21 \mathrm{~kg} \mathrm{P}^{-}$ ${ }^{1}+30 \mathrm{~kg} \mathrm{~S} \mathrm{ha}^{-1}$ ) were to sub-plots. The area of each plot was $12 \mathrm{~m}^{2}$. Three central rows were harvested, 3 rows were used for distractive samples, and the marginal rows were used as border rows. Spacing between plots and blocks were $1.5 \mathrm{~m}$

\subsection{Experimental Procedures}

Snap bean "Plati" variety was used for experiment at a spacing of 50 and $10 \mathrm{~cm}$ between rows and plants, respectively. $\mathrm{P}$ and $\mathrm{S}$ fertilizers were applied at sowing in the form of TSP $\left(46 \% \mathrm{P}_{2} \mathrm{O}_{5}\right)$ and $\mathrm{K}_{2} \mathrm{SO}_{4}\left(51 \% \mathrm{~K}_{2} \mathrm{O}\right.$ and $18 \% \mathrm{~S})$, respectively. $\mathrm{KCl}\left(60 \% \mathrm{~K}_{2} \mathrm{O}\right.$ and $\left.48 \% \mathrm{Cl}\right)$ was used to balance the supply of $\mathrm{K}$ applied through $\mathrm{K}_{2} \mathrm{SO}_{4}$. Irrigation treatment was carried out when plants reached the first two true leaves stage.

\section{Soil samples collection and analysis}

Composite soil samples were collected from representative 12 spots using diagonal sampling method by using auger at a depth of 0-20, 20-40 and 40-60 cm for physico-chemical soil analysis. Bulk density $\left(\mathrm{g} \mathrm{cm}^{-3}\right)$ was determined from undisturbed soil using core sampler. Electrical conductivity $\left(\mathrm{dS} \mathrm{m}^{-1}\right)$ was analyzed on a 1:2.5 soil: $\mathrm{H}_{2} \mathrm{O}$ suspension using a conductivity meter (Sahelemedhin and Taye, 2000). Soil pH was determined on a 1:2.5 soil: $\mathrm{H}_{2} \mathrm{O}$ solution suspension using a $\mathrm{pH}$ meter. Organic carbon (\%) was determined using wet oxidation method. Organic matter (\%) was calculated by multiplying the OC\% by a factor of 1.724 . Total N (\%) was determined by using Micro-Kjeldahl digestion. Available $\mathrm{P}\left(\mathrm{mg} \mathrm{kg}^{-1}\right)$ was determined by Olsen's method (Cottenie et al., 1982). Exchangeable K was determined by using flame photometer (Hesse, 1971). Available S $\left(\mathrm{mg} \mathrm{kg}^{-1}\right)$ was estimated by turbidity.

\section{Estimation of soil water characteristics}

Measurement of soil moisture

Moist soil weight (W) was determined by weighing the sample at the time of soil sampling and dry weight was obtained after drying the sample to a constant weight in an oven at $105^{\circ} \mathrm{C}$ for $24 \mathrm{hrs}$ (Hillel, 1980).

$$
\mathrm{W}=\frac{\text { Wet soil weight }- \text { Dry soil weight }}{\text { Dry soil weight }} * 100
$$

\section{Estimation of crop water requirement}

Initial soil water content for topsoil at the time of sowing was assumed to be close to field capacity due to preirrigation. Then, the proper amount of crop water requirement is the amount of daily ETo multiplied by Kc (Allen et al., 1998).

$$
\mathrm{ETc}=\mathrm{ETo} * \mathrm{Kc}
$$

Reference evapotranspiration (ETo) was estimated from weather data using CROPWAT windows version 8. Drip irrigation was applied based on ETo (FAO, 2009a) value of the previous day. The RAW was computed from the following equation:

$$
\mathrm{RAW}=\mathrm{p} * \mathrm{TAW}
$$

Where; RAW $=$ readily available soil moisture in the root zone $[\mathrm{mm}], \mathrm{p}=$ fraction for allowable soil moisture depletion for no stress, TAW = total available water [mm]

Net irrigation (IRn) was amount of irrigation water required to bring the soil moisture level in the effective root zone to field capacity (Michael, 2008).

$\mathrm{IRn}=\mathrm{ETc}-\mathrm{Pe}$

Where; $\mathrm{ETc}=$ crop evapotranspiration $\left[\mathrm{mm} \mathrm{day}^{-1}\right], \mathrm{Pe}=$ effective rainfall $[\mathrm{mm}]$ 


\subsection{Data Collected}

\section{Yield and yield components}

Number of pods plant ${ }^{-1}$ was determined by counting number of pods of 5 plants randomly selected in each plot. Fresh and dry pod weights ( $\mathrm{g}$ ) were estimated from the mean weights of 5 randomly selected plants in each plot. Snap bean pod yield were classified in two grades (Sunripe company manual, 2013). In the first grade, pods should be turgid, easily snapped, very tender, straight, bright in color with a fresh appearance, and stringless. In the second grade, pod sizes were smaller and irregular in shapes. Total yield $\left(\mathrm{t} \mathrm{ha}^{-1}\right)$ was harvested from three central rows in each plot and all pods included regardless of their qualities.

\section{Pod quality parameters}

Pod length $(\mathrm{mm})$ was measured from the initial to the tip of the pods from the mean of 5 pods randomly selected in each plot using ruler. Pod diameter $(\mathrm{mm})$ was determined from the mean of 5 pods randomly selected in each plot using sieve by inserting the pods into the appropriate hole best fitting for the pod size. Pod texture was determined at harvest maturity stages from the following five visual scales $(1=$ very fine, $2=$ fine, $3=$ reasonably fine, $4=$ coarse/rough, $5=$ very coarse/rough). Pod appearance was recorded at harvest maturity stages from 5 visual scales $(1=$ excellent, $2=$ good, $3=$ acceptable, $4=$ poor, $5=$ rejected $)$. Pod curvature was recorded at harvest maturity stages from 4 visual scales ( $1=$ straight, $2=$ slightly straight, $3=$ curved, $4=$ re-curved) (Hussein et al., 2015).

\subsection{Stastical Data Analysis}

All data were subjected to analysis of variance using the GLM procedure of the SAS software version 9.0 (SAS, 2004). The assumptions of ANOVA for normality of distribution and homogeneity of variance was checked, and statistical analyses where the F-ratios was found to be significant, mean separation was performed using LSD at the $5 \%$ probability level.

\section{Result and Discussions}

\subsection{Physico-Chemical Properties of the Soil}

Soil textural class and bulk density was loam and low, respectively in table 1 . Soil pH was 7.40 at all soil depths and is moderately alkaline (Motsara and Roy, 2008). Electrical conductivity of soil tested was free of salinity. Organic carbon at all soil depths, which could be rated as medium. Organic matter (OM) at a depth of 0-20 and $20-40 \mathrm{~cm}$, which showed that high rating. However, OM at a depth of $40-60 \mathrm{~cm}$, which could be rated as moderating (Hazelton and Murphy, 2007). Total $\mathrm{N}$ from all soil depths, which indicated low rating. Exchangeable K from a depth of 0-20, 20-40 and 40-60 cm (Table 2) was rated as very high. Available $\mathrm{P}$ at a depth of $0-20 \mathrm{~cm}$ was rated as medium, while at a depth of 20-40 and 40-60 $\mathrm{cm}$, which was rated as low. Available $\mathrm{S}$ at a soil depth of 0-20, 20-40 and 40-60 cm could be rated as medium (Goswam, 2014).

Table 1. Physical soil properties of experimental field before sowing

\begin{tabular}{cccccc}
\hline \multirow{2}{*}{$\begin{array}{c}\text { Soil depth } \\
(\mathrm{cm})\end{array}$} & $\begin{array}{c}\text { Bulk density } \\
\left(\mathrm{g} \mathrm{cm}^{-3}\right)\end{array}$ & \multicolumn{3}{c}{ Particles size distribution (\%) } & \multirow{2}{*}{ Textural classes } \\
\cline { 3 - 4 } & 1.01 & 31.25 & 21.25 & Silt & \\
\hline $0-20$ & 1.07 & 41.25 & 18.75 & 47.50 & Loam \\
$20-40$ & 1.06 & 41.25 & 18.75 & 40.00 & Loam \\
$40-60$ & & & 40.00 & Loam \\
\hline
\end{tabular}

Table 2. Chemical soil properties of experimental field before sowing

\begin{tabular}{ccccccccc}
$\begin{array}{c}\text { Soil depth } \\
(\mathrm{cm})\end{array}$ & $\mathrm{pH}$ & $\begin{array}{c}\mathrm{EC} \\
\left.(\mathrm{dS} \mathrm{m})^{-1}\right)\end{array}$ & $\begin{array}{c}\mathrm{OC} \\
(\%)\end{array}$ & $\begin{array}{c}\mathrm{OM} \\
(\%)\end{array}$ & $\begin{array}{c}\mathrm{TN} \\
(\%)\end{array}$ & $\begin{array}{c}\text { Ava. P } \\
\left(\mathrm{mg} \mathrm{kg}^{-1}\right)\end{array}$ & $\begin{array}{c}\text { Exc. K (cmol } \\
\left.(+) \mathrm{kg}^{-1}\right)\end{array}$ & $\begin{array}{c}\text { Ava. S } \\
\left(\mathrm{mg} \mathrm{kg}^{-1}\right)\end{array}$ \\
\hline $0-20$ & 7.25 & 0.27 & 2.96 & 5.11 & 0.09 & 13.53 & 2.26 & 16.43 \\
$20-40$ & 7.35 & 0.33 & 2.57 & 4.44 & 0.08 & 8.81 & 2.37 & 15.35 \\
$40-60$ & 7.58 & 0.27 & 2.50 & 4.30 & 0.07 & 5.66 & 2.54 & 14.26 \\
\hline
\end{tabular}

\subsection{Yield and Yield Components Number of pods per plant}

Application of various irrigation regimes had brought significant $(P \leq 0.05)$ effect on number of pods plant ${ }^{-1}$, but the use fertilizers and their interactions didn't showed significant effect on number pods plant ${ }^{-1}$ in both years. The highest number of pods plant ${ }^{-1}$ were obtained at $100 \%$ ETc, while the lowest pod numbers plants ${ }^{-1}$ were recorded from 55\% ETc (Table 3). Similar with Onder et al. (2006) reduction of number of pods plant ${ }^{-1}$ due to water stress and associated with reduction in the photosynthetic chlorophyll pigments. 
Table 3. Mean value of number pods plant $^{-1}$ and $2^{\text {nd }}$ grade pod yield parameters as influenced by different irrigation regimes and fertilizers applications on snap bean in 2017 and 2018.

\begin{tabular}{|c|c|c|c|c|c|c|}
\hline \multirow{2}{*}{$\begin{array}{c}\text { Fertilizers } \\
\text { types }\left(\mathrm{kg} \mathrm{ha}^{-1}\right)\end{array}$} & \multicolumn{3}{|c|}{ Number of pods plant $^{-1}$} & \multicolumn{3}{|c|}{$2^{\text {nd }}$ grade pod yield $\left(\mathrm{t} \mathrm{ha}{ }^{-1}\right)$} \\
\hline & 2017 & 2018 & Combined & 2017 & 2018 & Combined \\
\hline Control & 9.62 & 9.99 & 9.80 & 1.40 & 1.92 & 1.66 \\
\hline P 21 & 9.51 & 9.28 & 9.40 & 1.32 & 1.64 & 1.48 \\
\hline $\mathrm{S} 30$ & 9.87 & 9.61 & 9.74 & 1.25 & 1.83 & 1.54 \\
\hline $\mathrm{P} 21+\mathrm{S} 30$ & 10.22 & 10.38 & 10.30 & 1.31 & 1.76 & 1.53 \\
\hline $\operatorname{LSD}(0.05)$ & NS & NS & NS & NS & NS & $\mathrm{NS}$ \\
\hline $\mathrm{CV}(\%)$ & 22.73 & 21.94 & 19.77 & 17.94 & 15.46 & 19.44 \\
\hline \multicolumn{7}{|c|}{ Irrigation Regimes (\%) } \\
\hline $55 \mathrm{ETC}$ & $7.81^{\mathrm{b}}$ & $8.29^{\mathrm{b}}$ & $8.64^{b}$ & $1.19^{c}$ & 1.67 & 1.42 \\
\hline $70 \mathrm{ETC}$ & $9.90^{\mathrm{ab}}$ & $9.40^{\mathrm{b}}$ & $9.10^{\mathrm{b}}$ & $1.16^{\mathrm{bc}}$ & 1.71 & 1.43 \\
\hline $85 \mathrm{ETC}$ & $9.93^{\mathrm{ab}}$ & $9.48^{b}$ & $10.46^{\mathrm{a}}$ & $1.40^{\mathrm{ab}}$ & 1.71 & 1.56 \\
\hline $100 \mathrm{ETC}$ & $11.53^{\mathrm{a}}$ & $12.10^{\mathrm{a}}$ & $11.02^{\mathrm{a}}$ & $1.53^{\mathrm{a}}$ & 2.07 & 1.80 \\
\hline $\operatorname{LSD}(0.05)$ & 2.76 & 2.01 & 1.15 & 0.24 & $\mathrm{NS}$ & $\mathrm{NS}$ \\
\hline $\mathrm{CV}(\%)$ & 28.34 & 20.49 & 11.74 & 23.77 & 25.11 & 26.12 \\
\hline
\end{tabular}

Means within each column with different letters are significantly different using LSD at $P \leq 0.05$

\section{Fresh and dry pod weight}

Irrigation regimes had brought significant $(P \leq 0.05)$ effect on fresh and dry pod weights in both years. However, the application fertilizers and their interactions had non-significant effect on fresh and dry pod weights. The highest fresh and dry pod weight were obtained from $100 \%$ ETc, while the lowest fresh and dry pod weight were obtained from 55\% ETc (Table 4). Agreement with Onder et al. (2006) under low irrigation regimes, fresh and dry pod weights of snap bean were decreased.

Table 4. Mean value of fresh and dry pod weight plant $^{-1}$ parameters as influenced by different irrigation regimes and fertilizers application on snap bean in both 2017 and 2018.

\begin{tabular}{|c|c|c|c|c|c|c|}
\hline \multirow{2}{*}{$\begin{array}{l}\text { Fertilizers types } \\
\quad\left(\mathrm{kg} \mathrm{ha}^{-1}\right)\end{array}$} & \multicolumn{3}{|c|}{ Pod fresh weight plant $^{-1}(\mathrm{gm})$} & \multicolumn{3}{|c|}{ Pod dry weight plant $^{-1}(\mathrm{gm})$} \\
\hline & 2017 & 2018 & Combined & 2017 & 2018 & Combined \\
\hline 0 & 59.20 & 51.94 & 55.58 & 5.05 & 7.13 & 6.10 \\
\hline $\mathrm{P} 21$ & 51.11 & 46.93 & 49.02 & 4.20 & 8.56 & 6.40 \\
\hline $\mathrm{S} 30$ & 47.27 & 45.70 & 46.48 & 4.03 & 8.38 & 6.20 \\
\hline $\mathrm{P} 21+\mathrm{S} 30$ & 50.25 & 50.36 & 50.31 & 4.21 & 8.19 & 6.22 \\
\hline $\operatorname{LSD}(0.05)$ & $\mathrm{NS}$ & $\mathrm{NS}$ & $\mathrm{NS}$ & $\mathrm{NS}$ & $\mathrm{NS}$ & $\mathrm{NS}$ \\
\hline $\mathrm{CV}(\%)$ & 24.21 & 27.74 & 18.91 & 22.41 & 20.03 & 23.52 \\
\hline \multicolumn{7}{|c|}{ Irrigation Regimes (\%) } \\
\hline $55 \mathrm{ETC}$ & $45.74^{\mathrm{b}}$ & $37.63^{\mathrm{b}}$ & $41.68^{c}$ & $3.89^{\mathrm{b}}$ & $7.06^{\mathrm{b}}$ & $5.5 b$ \\
\hline $70 \mathrm{ETC}$ & $50.14^{\mathrm{a}}$ & $44.45^{\mathrm{b}}$ & $47.30^{\mathrm{bc}}$ & $4.40^{\mathrm{a}}$ & $8.08^{\mathrm{ab}}$ & $5.89 \mathrm{ab}$ \\
\hline 85 ETC & $55.28^{a}$ & $45.96^{\mathrm{b}}$ & $51.32^{\mathrm{b}}$ & $4.51^{\mathrm{a}}$ & $8.24^{\mathrm{ab}}$ & $6.25 \mathrm{ab}$ \\
\hline $100 \mathrm{ETC}$ & $56.70^{\mathrm{a}}$ & $66.88^{\mathrm{a}}$ & $61.09^{\mathrm{a}}$ & $4.68^{\mathrm{a}}$ & $10.03^{\mathrm{a}}$ & $7.28 \mathrm{a}$ \\
\hline $\operatorname{LSD}(0.05)$ & 11.32 & 14.84 & 5.57 & 1.32 & 2.04 & 1.8 \\
\hline $\mathrm{CV}(\%)$ & 27.30 & 30.50 & 15.06 & 27.83 & 25.36 & 22.63 \\
\hline
\end{tabular}

Means within each column with different letters are significantly different using LSD at $P \leq 0.05$

\section{First grade pod yield}

Irrigation regimes and interaction effect had brought highly significant $(P \leq 0.01)$ effect on first grade pod yield. However, the application of fertilizers had non-significant on $1^{\text {st }}$ grade pod yield. Higher $1^{\text {st }}$ grade pod yield was recorded from interaction of $100 \%$ ETc with all fertilizers, whereas lower $1^{\text {st }}$ grade pod yield was obtained from interactions of 55\% ETc with S30 and P21+S30 kg ha-1 (Table 5). Similar with Gupta et al. (2017) who reported that under low irrigation regimes, stomata openings are closed by signals from roots leading to reduction in leaf gas exchange and the mechanism ultimately lead to decreased pod yield. 
Table 5. Interaction effect of various irrigation regimes and fertilizers application on $1^{\text {st }}$ grade pod yield and total pod yield of snap bean

\begin{tabular}{|c|c|c|c|c|c|c|c|c|}
\hline \multirow{3}{*}{$\begin{array}{c}\text { Irrigation } \\
\text { regimes }(\%)\end{array}$} & \multicolumn{4}{|c|}{$1^{\text {st }}$ grade pod yield $\left(\mathrm{t} \mathrm{ha}{ }^{-1}\right)$} & \multicolumn{4}{|c|}{ Total pod yield $\left(\mathrm{t} \mathrm{ha}^{-1}\right)$} \\
\hline & \multicolumn{8}{|c|}{$\overline{\text { Fertilizers types }\left(\mathrm{kg} \mathrm{ha}^{-1}\right)}$} \\
\hline & 0 & $\mathrm{P} 21$ & $\mathrm{~S} 30$ & $\mathrm{P} 21+\mathrm{S} 30$ & 0 & $\mathrm{P} 21$ & $\mathrm{~S} 30$ & $\mathrm{P} 21+\mathrm{S} 30$ \\
\hline 55 ETc & $3.47^{\mathrm{fg}}$ & $4.46^{\mathrm{ef}}$ & $2.89^{g}$ & $3.25^{\mathrm{g}}$ & $5.75^{\mathrm{gh}}$ & $7.41^{\mathrm{efg}}$ & $5.36^{\mathrm{h}}$ & $6.57^{\mathrm{gh}}$ \\
\hline 70 ETc & $5.61^{\mathrm{cd}}$ & $3.39^{\mathrm{fg}}$ & $5.37^{\mathrm{de}}$ & $5.00^{\mathrm{de}}$ & $8.93^{\mathrm{def}}$ & $7.00^{\mathrm{gh}}$ & $9.17^{\text {cde }}$ & $7.25^{\text {fgh }}$ \\
\hline 85 ETc & $6.58^{\mathrm{c}}$ & $8.39^{\mathrm{b}}$ & $6.04^{\mathrm{cd}}$ & $6.58^{c}$ & $9.32^{\text {cd }}$ & $10.98^{\mathrm{bc}}$ & $9.72^{\mathrm{cd}}$ & $9.99^{\mathrm{cd}}$ \\
\hline $100 \mathrm{ETc}$ & $9.63^{\mathrm{a}}$ & $9.31^{\mathrm{ab}}$ & $9.19^{\mathrm{ab}}$ & $9.46^{\mathrm{ab}}$ & $13.75^{\mathrm{a}}$ & $12.53^{\mathrm{ab}}$ & $13.48^{\mathrm{a}}$ & $12.36^{\mathrm{ab}}$ \\
\hline $\operatorname{LSD}(0.05)$ & \multicolumn{4}{|c|}{1.08} & \multicolumn{4}{|c|}{1.78} \\
\hline $\mathrm{CV}(\%)$ & \multicolumn{4}{|c|}{10.51} & \multicolumn{4}{|c|}{11.32} \\
\hline
\end{tabular}

Means within each column with different letters are significantly different using LSD at P $\leq 0.05$

\section{Total pod yield}

Irrigation regimes and their interactions had a significant $(P \leq 0.05)$ effect on total pod yield, but fertilizers nonsignificant effect on total pod yield. Higher total pod yield was recorded from interaction of $100 \%$ ETc with all fertilizers, whereas the lowest total pod yield was obtained from interaction of 55\% ETc with S30 (Table 5). Similar with those Abdel-Mawgoud (2006) increasing irrigation regimes, increased total pod yield due to increased applied water, which improved moisture content in the soil.

\subsection{Pod Quality Parameters}

\section{Pod length}

Irrigation regimes had brought highly significant $(P \leq 0.01)$ effect on pod length, but the application of fertilizers and their interactions non-significant effect on pod length. The highest pod length was recorded from $100 \%$ ETc in both years, while the lowest pod length was obtained from 55\% ETc (Table 6). Similar with Hosny et al. (2015) low irrigation regime decrease pod length of snap beans, which is due to water stress conditions.

\section{Pod diameter}

Irrigation regimes, fertilizers and their interactions, didn't show any significant effect on pod diameter (Table 6). As irrigation regimes increases, pod diameter numerically increased. Contrast to this study Abdel-Mawgoud (2006) pod diameter increased with increasing irrigation level up to the full irrigation application.

Table 6. Mean value of pod length and diameter parameters as influenced by different irrigation regimes and fertilizers applications on snap bean in 2017 and 2018.

\begin{tabular}{|c|c|c|c|c|c|c|}
\hline \multirow{2}{*}{$\begin{array}{l}\text { Fertilizer types } \\
\quad\left(\mathrm{kg} \mathrm{ha}^{-1}\right)\end{array}$} & \multicolumn{3}{|c|}{ Length (mm) } & \multicolumn{3}{|c|}{ Diameter $(\mathrm{mm})$} \\
\hline & 2017 & 2018 & Combined & 2017 & 2018 & Combined \\
\hline 0 & 130.77 & 134.6 & 132.70 & 8.74 & 8.50 & 8.62 \\
\hline P 21 & 130.65 & 133.6 & 132.13 & 8.81 & 8.29 & 8.55 \\
\hline S 30 & 133.33 & 132.5 & 132.91 & 8.79 & 8.44 & 8.61 \\
\hline $\mathrm{P} 21+\mathrm{S} 30$ & 130.37 & 132.6 & 131.49 & 8.83 & 8.29 & 8.56 \\
\hline $\operatorname{LSD}(0.05)$ & NS & NS & NS & $\mathrm{NS}$ & NS & $\mathrm{NS}$ \\
\hline CV $(\%)$ & 3.60 & 4.68 & 2.73 & 3.56 & 4.64 & 2.69 \\
\hline \multicolumn{7}{|c|}{ Irrigation Regimes (\%) } \\
\hline $55 \mathrm{ETC}$ & $126.94^{b}$ & $127.87^{\mathrm{c}}$ & $128.51^{\mathrm{c}}$ & 8.64 & 8.19 & 8.50 \\
\hline $70 \mathrm{ETC}$ & $129.15^{\mathrm{ab}}$ & $132.33^{\mathrm{bc}}$ & $129.64^{\mathrm{bc}}$ & 8.76 & 8.36 & 8.53 \\
\hline $85 \mathrm{ETC}$ & $133.33^{\mathrm{ab}}$ & $133.77^{b}$ & $133.55^{\mathrm{ab}}$ & 8.88 & 8.46 & 8.61 \\
\hline $100 \mathrm{ETC}$ & $135.70^{\mathrm{a}}$ & $139.35^{\mathrm{a}}$ & $137.53^{\mathrm{a}}$ & 8.89 & 8.52 & 8.70 \\
\hline $\operatorname{LSD}(0.05)$ & 5.9 & 4.82 & 4.60 & NS & NS & NS \\
\hline $\mathrm{CV}(\%)$ & 5.08 & 3.62 & 3.48 & 2.88 & 6.74 & 4.04 \\
\hline
\end{tabular}

Means within each column with different letters are significantly different using LSD at $P \leq 0.05$

Pod texture, appearance and curvature

Pod texture, appearance, and curvature of snap bean were influenced by irrigation regimes. The highest fine pod texture, excellent pod appearance, and straight pod curvature was recorded from $100 \%$ ETc, whereas the highest coarse pod texture, less attractive pod appearance, and curved pod curvature was obtained from 55\% ETc (Figure 2). Fit with Sezen et al. (2008) pod color brightness and appearance improve as the irrigation regime increased. 


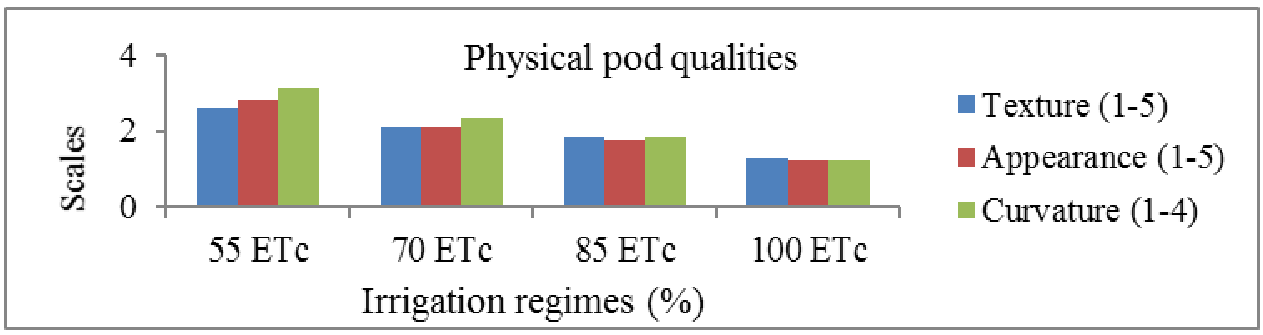

Figure 2. Mean of pod texture, appearance and curvature of snap bean influenced by irrigation regimes

\subsection{Partial Budget Analysis}

Partial budget analysis indicated that the best treatment was 100\% ETc without fertilizers application, which gave highest net benefits 160,242.6 ETB ha ${ }^{-1}$ and also the second alternative recommendation from $85 \%$ ETc without fertilizers application, which gave 111,879.2 ETB ha ${ }^{-1}$ net benefits with an acceptable marginal rate of returns for snap bean production in table 7.

Table 7. Dominance analysis and marginal rate of returns of interaction effect of different irrigation regimes and fertilizers applications on marketable pod yield of snap bean

\begin{tabular}{|c|c|c|c|c|c|c|c|}
\hline \multicolumn{2}{|c|}{ Treatments } & $\begin{array}{l}\text { T. variable } \\
\text { cost }(\text { ETB } \\
\left.\mathrm{ha}^{-1}\right)\end{array}$ & $\begin{array}{l}\text { Net benefit } \\
\left(\text { ETB ha }^{-1}\right)\end{array}$ & Dominance & $\begin{array}{c}\text { Marginal } \\
\text { cost } \\
\left(\mathrm{ETB} \mathrm{ha}^{-1}\right)\end{array}$ & $\begin{array}{l}\text { Marginal } \\
\text { benefits } \\
\left(\mathrm{ETB} \mathrm{ha}^{-1}\right)\end{array}$ & $\begin{array}{c}\text { Marginal } \\
\text { rate returns } \\
(\%)\end{array}$ \\
\hline $55 \%$ ETc & \multirow{4}{*}{0} & 372.6 & 65372.4 & & - & - & - \\
\hline $70 \%$ ETc & & 474.2 & 105770.8 & & 101.6 & 40398 & 39758.29 \\
\hline $85 \%$ ETc & & 575.8 & 111879.2 & & 101.6 & 6108 & 6011.61 \\
\hline $100 \%$ ETc & & 677.4 & 160242.6 & & 101.6 & 48363 & 47597.09 \\
\hline $55 \%$ ETc & \multirow{4}{*}{ P21 } & 882.1 & 83222.9 & Dominated & & & \\
\hline $70 \%$ ETc & & 983.7 & 68176.3 & Dominated & & & \\
\hline $85 \%$ ETc & & 1085.3 & 129864.7 & Dominated & & & \\
\hline $100 \%$ ETc & & 1186.9 & 147853.1 & Dominated & & & \\
\hline $55 \%$ ETc & \multirow{4}{*}{$\mathrm{S} 30$} & 1299.6 & 55535.4 & Dominated & & & \\
\hline $70 \%$ ETc & & 1401.2 & 92693.8 & Dominated & & & \\
\hline $85 \%$ ETc & & 1502.8 & 107577.2 & Dominated & & & \\
\hline $100 \%$ ETc & & 1604.4 & 154320.6 & Dominated & & & \\
\hline $55 \%$ ETc & \multirow{4}{*}{$\mathrm{P} 21+\mathrm{S} 30$} & 1689.1 & 71480.9 & Dominated & & & \\
\hline $70 \%$ ETc & & 1790.7 & 82044.3 & Dominated & & & \\
\hline $85 \%$ ETc & & 1892.3 & 110562.7 & Dominated & & & \\
\hline $100 \%$ ETc & & 1993.9 & 151231.1 & Dominated & & & \\
\hline
\end{tabular}

\section{Conclusion and Recommendation}

Snap bean is the most important exporting vegetable crop grown for young edible and fleshly pods. Snap bean production in Ethiopia has increased from year to year both for export and local markets, but their productivity is very low and poor quality due to inadequate moisture and soil fertility problems. Water stress at the critical stage can reduce snap bean yield and quality. On the other hand, a major problem of snap bean production in Ethiopia is poor soil fertility.

The interaction effect had brought significant effect on first grade yield and total pod yield. The main effect of irrigation regimes had a significant effect in all yield and quality parameters except, second grade pod yield and pod diameter. On the other hand; the main effect of fertilizers applications didn't showed significant effect in all parameters. Lack of response by the snap bean to the three fertilizer types could partially be attributed to the medium level of soil availability for both nutrients, P and S. Based on the current findings, 85 and $100 \%$ ETc without fertilizer applications, which gave higher yield and better quality. Therefore, snap bean producers could consider $85 \%$ ETc without fertilizer applications where irrigation water is a limiting factor and $100 \%$ ETc without fertilizer applications where there are no water shortages in the central rift valley of Ethiopia with similar soil properties.

\section{Acknowledgement}

I would like to express my sincere appreciation to EIAR for providing me financial support. My special thanks goes to vegetable research program staff at MARC for providing me financial support. Moreover, my heartfelt thank goes to MARC staff specially, Tewodrose Mesfine (Ph.D.), Daniel Bekele (Ph.D. Eng), Mr. Gobena Dirirsa and Tilahun Hordofa (Ph.D. Eng) for giving me constructive comment and guidance. Thanks to School 
of Graduate Studies of Hawassa University, College of Agriculture for educating me.

\section{References}

Abdel-Mawgoud, A.M.R. 2006. Growth, yield and quality of green bean in response to irrigation and compost applications. J. Apl. Sci. Res., 2(7):443-450.

Alemu Lelago,Tekalign Mamo, Wassie Haile and Hailu Shiferaw. 2016. Assessment and mapping of status and spatial distribution of soil macronutrients in Kambata Tembaro Zone, Southern Ethiopia. Adv. Pla. Agr. Res., 4(4):1-14.

Allen, R.G., Pereira, L.S., Raes, D. and Smith, M. 1998. Crop evapotranspiration, FAO, Irrigation and Drainage Paper $\mathrm{N}^{\circ} 56$, FAO, Rome, Italy.

ATA. 2015. Soil fertility mapping and fertilizer recommendation in Ethiopia: Update of EthioSIS project and status of fertilizer blending plants.

CIAT. 2006. Highlights of CIAT in Africa: Snap beans for income generation by small farmers in East Africa. Series. No.31:

Girma Abebe. 2009. Effect of NP fertilizer and moisture conservation on the yield and yield components of haricot bean (Phaseolus vulgaris L.) in the semi-arid zones of the central rift valley in Ethiopia. Adv. Env. Bio., 3(3):302-307.

Gupta, S., Kushwah, S.S., Sharma, R.K. and Singh, O.P. 2017. Effect of irrigation regimes and nutrient levels on growth, yield and quality of drip irrigated broad bean (Vicia faba L.). Ind. J. Agr. Sci., 87(10):1314-1319.

Hazelton, P. and Murphy, B. 2007. Interpreting soil test results: What do all the number mean? $2^{\text {nd }}$ eds. CSIRO Publishing, Victoria, Australia. 160 p.

Hosny, M.M., El-Dayem, A., Mohamed, A.M., Mohamed, M.M., El-All, A. and Rania, S.M. 2015. Effect of some antioxidants, potassium and arbuscular mycorrhiza on growth, yield and quality of snap bean plants grown under water stress levels. Annals of Agri. Sci. Moshtohor, 53 (1):15-30.

Hussein Mohammed, Frances, L.W., Rosalind, B. and Bunyamin, T. 2015. Response of snap bean cultivars to Rhizobium inoculation under dry land Agriculture in Ethiopia. Agronomy, 5:291-308.

Sunripe Company Manual. 2013. Production and raw material product specifications of runner beans for export.

Tesfaye Wossen. 2017. Determination of optimum rate of blended fertilizer for pod yield of snap bean at Teda, North Gondar, Ethiopia. Int. J. Sci. Bas. and Apl. Res., 32 (2):66-79. 